\title{
ANALISIS PELAKSANAAN NILAI-NILAI SIKAP ANTI KORUPSI DALAM PEMBELAJARAN PENDIDIKAN KEWARGANEGARAAN SISWA KELAS VII DI SMP O2 MUHAMMADIYAH PONTIANAK
}

\author{
Muhammad Anwar Rube'i ${ }^{1}$, Defiana Sari ${ }^{2}$ \\ ${ }^{1,2}$ Program Studi PPKn Fakultas Ilmu Pendidikan dan Pengetahuan Sosial IKIP-PGRI Pontianak \\ Jl. Ampera No.88 Telp. (0561) 748219 Fax. (0561) 6589855 \\ email: anwarptk87@gmail.com
}

\begin{abstract}
Abstrak
Penelitian ini berrtujuan untuk mengetahui pelaksanaan nilai-nilai sikap anti korupsi dalam pembelajaran Pendidikan Kewarganegaraan di SMP 02 Muhammadiyah Pontianak. Penelitian ini menggunakan pendekatan kuantitatif dengan metode survei. Alat pengumpul Data yang digunakan adalah angket, panduan wawancara dan dokumen. Teknik analisis data menggunakan perhitungan statistik rumus persentase. Berdasarkan hasil pengolahan dan analisis data maka secara umum dapat disimpulkan bahwa Analisis pelaksanaan nilai-nilai sikap anti korupsi dalam pembelajaran pendidikan kewarganegaraan pada siswa kelas VII SMP muhammadiyah Pontianak memperoleh skor aktual 3060 dan skor ideal 3600 dengan angka persentase mencapai $85 \%$ dengan kategori sangat baik.
\end{abstract}

Kata Kunci: Pelaksanaan Nilai-nilai Sikap Anti Korupsi, Pembelajaran Pendidikan Kewarganegaraan

\begin{abstract}
This study aims to determine the implementation of anti-corruption attitudes in the learning of citizenship education in SMP 02 Muhammadiyah Pontianak. This research uses a quantitative approach with a survey method. Data collection tools used were questionnaires, interview guides and documents. The data analysis technique uses the percentage formula statistical calculations. Based on the results of data processing and analysis, in general it can be concluded that the analysis of the implementation of anti-corruption attitudes in the learning of citizenship education in grade VII students of Pontianak Muhammadiyah Pontianak obtained an actual score of 3060 and an ideal score of 3600 with a percentage reaching $85 \%$ with the category of Very Good.
\end{abstract}

Keywords: Implementation of the Values of Anti-Corruption Attitudes, Learning Citizenship Education

\section{PENDAHULUAN}

Reformasi telah bergulir lebih dari satu dekade semenjak lengsernya Presiden Soeharto pada tahun 1998. Salah satu agenda penting reformasi adalah pemberantasan tindak pidana korupsi yang terjadi selama rezim orde baru sampai saat ini. Semua kalangan masyarakat menginginkan agenda mendesak tersebut segera terlaksana dan dituntaskan. Kekuasaan rezim orde baru yang terlalu lama dan absolut telah menumbuhkan prilaku korupsi yang mengakar dan sulit sekali untuk diberantas. Korupsi dan kekuasaan tersebut di atas sesuai dengan ungkapan Acton dalam Djaja (2010: 19) bahwa "power tends to corrupt, but absolute power currupt absolutelly".

Situasi ini berubah dengan drastis waktu - setelah lengsernya Suharto pada 1998 - program desentralisasi daerah yang ambisius dimulai pada tahun 2001 yang meramalkan pemindahan otonomi administrasi dari Jakarta ke kabupaten (bukan ke provinsi). Program baru ini sejalan dengan tuntutan masyarakat tetapi memiliki efek samping negatif pada pola distribusi korupsi. Penyuapan tidak lagi 'dikoordinasikan' seperti yang telah terjadi di masa lalu tapi menjadi terpecah-pecah dan tidak jelas. Desentralisasi berarti bahwa pemerintah daerah mulai membuat 
peraturan daerah baru (sering tidak dirancang dengan ketat) yang memungkinkan para pejabat lainnya dari berbagai tingkat pemerintah dan lembaga lainnya untuk berbaur dan meminta tambahan keuangan.

Menyadari kebutuhan mendesak untuk mengatasi korupsi (karena merusak iklim investasi dan bisnis serta, umumnya, mendorong adanya ketidakadilan terus-menerus dalam masyarakat), sebuah badan pemerintah baru didirikan pada tahun 2003. Lembaga pemerintah ini, Komisi Pemberantasan Korupsi (disingkat KPK), ditugaskan untuk membebaskan Indonesia dari korupsi dengan menyelidiki dan mengusut kasus-kasus korupsi serta memantau tata kelola negara (yang menerima kekuasaan yang luas untuk melakukan tugasnya).

Meskipun sebagian besar gambarannya (di atas) negatif, ada beberapa tanda-tanda positif. Pertama-tama perlu disebutkan bahwa ada dorongan besar dari rakyat Indonesia untuk memberantas korupsi di Indonesia dan media yang bebas memberikan banyak ruang untuk menyampaikan suara mereka pada skala nasional, sementara para lembaga media juga asyik berfokus pada skandal-skandal korupsi (meskipun beberapa institusi media yang dimiliki oleh politisi atau pengusaha memiliki agendanya sendiri untuk melakukan hal ini). Dorongan rakyat untuk memberantas korupsi berarti bahwa "bersikap anti-korupsi" sebenarnya bisa menjadi votegainer (pendulang suara) yang penting bagi politisi yang bercita-cita tinggi. Terlibat atau disebutkan dalam kasus korupsi benar-benar bisa merusak karir karena dukungan rakyat akan merosot drastis. Efek samping negatif (bagi perekonomian negara) dari pengawasan publik ini yaitu pejabat pemerintah saat ini sangat berhati-hati dan ragu-ragu untuk mengucurkan alokasi anggaran pemerintahan mereka, takut menjadi korban dalam skandal korupsi. Perilaku berhatihati ini bisa disebut sebagai keberhasilan pengaruh KPK yang memantau aliran uang, tetapi juga menyebabkan belanja pemerintah yang lambat.

Transparency International, institusi non-partisan yang berbasis di Berlin (Jerman), menerbitkan Indeks Persepsi Korupsi tahunan (berdasarkan polling) yang menilai "sejauh mana korupsi dianggap terjadi di kalangan pejabat publik dan politisi" di semua negara seluruh dunia. Indeks Persepsi Korupsi Tahunan ini menggunakan skala dari satu sampai sepuluh. Semakin tinggi hasilnya, semakin sedikit (dianggap) korupsi yang terjadi. Dalam edisi terbaru mereka (2018) Indonesia menempati peringkat 96 (dari total 180 negara). Meskipun demikian, perlu ditekankan bahwa tidak ada metode yang akurat 100 persen untuk mengukur korupsi karena sifat korupsi (sering tersembunyi untuk umum). Maka angka-angka di bawah ini hanya menunjukkan tingkat persepsi korupsi oleh para pemilih yang berpartisipasi dalam jajak pendapat dari negara tertentu.

Indeks Perilaku Anti Korupsi (IPAK) masyarakat Indonesia pada tahun 2018 lebih rendah dari tahun sebelumnya. Data Badan Pusat Statistik (BPS) menunjukan IPAK tahun ini berada di 
level 3,66 dari skala 0-5, tahun sebelumnya berada di 3,71. Semakin tinggi indeks mengindikasikan semakin tinggi perilaku masyarakat yang anti korupsi. Sebaliknya, semakin rendah indeks maka semakin rendah perilaku anti korupsi. Namun karena masyarakat biasanya memiliki pemahaman yang baik tentang apa yang sedang terjadi di negeranya, angka-angka ini pasti mengindikasikan sesuatu yang menarik dan angka-angka ini menunjukkan bahwa (sesuai dengan teks di atas) ada pandangan umum yang agak negatif mengenai tingkat korupsi politik di Indonesia. Namun, ketika kita mempertimbangkan hasil sebelumnya, indeks korupsi menunjukkan tren yang lebih positif.

Terkait dengan korupsi, masih ada jalan panjang reformasi ke depan untuk Indonesia. Baik pada tingkat pusat dan daerah, bisnis dan politik masih cenderung "pergi tangan-di-tangan", maka membentuk semacam konteks oligarki di mana konflik kepentingan terus terjadi. Misalnya, pembalakan liar tersebar luas di Sumatera dan Kalimantan karena banyak ijin penebangan liar dikeluarkan oleh badan-badan publik (sehingga mengancam keberadaan hutan di Indonesia). Demikian pula, di sektor pengadaan di Indonesia kontrak yang menguntungkan sering diberikan kepada perusahaan yang terkait dengan pejabat negara.

Korupsi sangat menghambat negara ini dalam merealisasikan potensi ekonomi dan menyebabkan ketidakadilan yang signifikan di dalam masyarakat Indonesia karena sebagian kecil orang mendapatkan manfaat yang amat besar dari lembaga dan keadaan korup di negeri ini. Tetapi pujian/penghargaan harus diberikan kepada media (bebas) Indonesia dan KPK karena keduanya memainkan peran penting dalam soal pemberantasan korupsi.

Faktor penyebab terjadinya korupsi diantaranya Penegakan hukum tidak konsisten penegakan hukum hanya sebagai meke-up politik, bersifat sementara dan selalu berubah tiap pergantian pemerintahan.Penyalahgunaan kekuasaan dan wewenang karena takut dianggap bodoh bila tidak menggunakan kesempatan. Rendahnya pendapatan penyelenggaraan negara. Pedapatan yang diperoleh harus mampu memenuhi kebutuhan penyelenggara negara, mampu mendorong penyelenggara negara untuk berprestasi dan memberikan pelayanan terbaik bagi masyarakat. Kemiskinan, keserakahan masyarakat kurang mampu melakukan korupsi karena kesulitan ekonomi. Sedangkan mereka yang berkecukupan melakukan korupsi karena serakah, tidak pernah puas dan menghalalkan segala cara untuk mendapatkan keuntungan. Konsekuensi bila ditangkap lebih rendah daripada keuntungan korupsi: saat tertangkap bisa menyuap penegak hukum sehingga dibebaskan atau setidaknya diringankan hukumannya.

Gagalnya pendidikan agama dan etika, ada benarnya pendapat Franz Magnis Suseno bahwa agama telah gagal menjadi pembendung moral bangsa dalam mencegah korupsi karena perilaku masyarakat yang memeluk agama itu sendiri. Pemeluk agama menganggap agama hanya berkutat 
pada masalah bagaimana cara beribadah saja. Sehingga agama nyaris tidak berfungsi dalam memainkan peran sosial. Menurut Franz, sebenarnya agama bisa memainkan peran yang besar dibandingkan institusi lainnya. Karena adanya ikatan emosional antara agama dan pemeluk agama tersebut jadi agama bisa menyadarkan umatnya bahwa korupsi dapat memberikan dampak yang sangat buruk baik bagi dirinya maupun orang lain.

Upaya pencegahan sebagai bentuk upaya pemberantasan korupsi yang dilakukan oleh pemerintah dapat dilakukan melalui penerimaan aparatur negara secara jujur dan terbuka. Kejujuran dan keterbukaan dalam penerimaan pegawai yang dilakukan oleh pemerintah menunjukkan usaha pemerintah yang serius untuk memberantas tindak pidana korupsi yang berkaitan dengan suap menyuap dalam penerimaan pegawai. Pemerintah yang sudah berupaya melakukan tindakan pencegahan dalam penerimaan pegawai perlu disambut baik oleh masyarakat terutama dalam mendukung upaya pemerintah tersebut.

Upaya edukasi yang dilakukan lembaga pendidik dalam usahanya untuk memberantas korupsi adalah upaya yang dilakukan melalui proses pendidikan. Proses pendidikan di Indonesia dilakukan dalam tiga jenis yaitu pendidikan formal, informal, dan non formal. Melalui proses edukasi, masyarakat diberikan pendidikan anti korupsi sejak dini agar masyarakat sadar betul akan bahaya korupsi bagi negara-negara khususnya negara Indonesia.

Selain itu, melalui edukasi yang diberikan oleh pemerintah, peranan mahasiswa dalam pemberantasan korupsi juga dapat dimaksimalkan sehingga para mahasiswa ini dapat memberikan contoh yang baik bagi adik-adiknya maupun bagi masyarakat umum terhadap cara pemberantasan korupsi dari dalam diri masing-masing. Upaya edukasi yang dilakukan oleh pemerintah juga termasuk sebagai upaya membangun karakter bangsa di era globalisasi untuk memberantas pertumbuhan budaya korupsi yang dapat merugikan kehidupan bermasyarakat dan bernegara.

Pendidikan Kewarganegaraan merupakan salah satu mata pelajaran di persekolahan yang mempunyai kontribusi penting dalam membentuk dan mewujudkan karakter bangsa yang dicitacitakan yaitu smart and goodcitizenship seperti ditegaskan dalam UU No. 20 Tahun 2003 dijelaskan bahwa aspek kepribadian warganegara yang perlu dikembangkan adalah menjadi manusia yang berkualitas sehingga mampu dan proaktif menjawab tantangan zaman.

Pendidikan Kewarganegaraan menjadi sangat strategis di tengah upaya pemerintah dalam membangun karakter bangsa mulai jenjang Sekolah Dasar sampai Perguruan Tinggi.Pendidikan Kewarganegaraan menjadi salah satu instrument yang fundamental dalam bingkai pendidikan nasional sebagai media pembentukan karakter bangsa (Zuriah, 2007:1). Berarti dalam hal ini Pendidikan Kewarganegaraan menanamkan nilai nilai dan kompetensi yang dimiliki oleh Pendidikan Kewarganegaraan untuk membentuk warga negara ideal, yaitu civic knowledge, civic 
skill, dan civic disposition. Pendapat di atas sejalan dengan misi Pendidikan Kewarganegaraan yaitu untuk mengembangkan warganegara yang demokratis, baik pengetahuan kewarganegaraan, watak atau karakter kewarganegaraan, dan keterampilan kewarganegaraan siswa yang nantinya bermuara pada terbentuknya good and smart citizenship. Ketiga kompetensi itu melahirkan good and smart citizen. Kestrategisan Pendidikan Kewarganegaraan untuk menanamkan nilai-nilai dapat dimaksimalkan sebagai transmisi nilai-nilai antikorupsi dalam pembelajaran Pendidikan Kewarganegaraan

Melihat dari tujuan pendidikan antikorupsi dengan tujuan Pendidikan Kewarganegaraan, mempunyai konsentrasi yang sama yakni pada perubahan perilaku utamanya adalah siswa untuk menjunjung tinggi sikap dan prilaku anti korupsi. Pendidikan Antikorupsi merupakan suatu upaya pemerintah dalam menciptakan generasi muda yang bersih dari tindakan tercela atau merusak moral bangsa khususnya Indonesia.

Terdapat beberapa aspek dalam mencegah dan meghilangkan korupsi, karena tidak hanya cukup melihat dari bidang hukum saja, Novitasari (2013: 2) mengungkapkan bahwa "kekuatan iman pun menjadi salah satu faktor terpenting dalam terbentuknya sikap antikorupsi”.Sependapat dengan hal tersebut, Atmasasmita, R. (2004: 13) mengungkapkan bahwa "strategi pemberantasan korupsi di Indonesia harus menggunakan empat pendekatan yaitu, pendekatan hukum, pendekatan moralistik dan keimanan, pendekatan edukatif dan pendekatan sosio-kultural.”

Pemberantasan korupsi melalui pendekatan edukatif adalah dengan Pendidikan Antikorupsi (PAk).Pendekatan edukatif dilakukan dengan alasan bahwa gerakan antikorupsi di Indonesia belum maksimal seperti yang diungkapkan oleh Kesuma, dkk (2009: 56) bahwa "gerakan antikorupsi Indonesia belum bersifat cukup". Selanjutnya dikatakan bahwa strategi anti korupsi hendaknya mencakup pendekatan jangka panjang dan jangka pendek, prevetif dan ponitif, serta symptom dan disease. Untuk memberantas korupsi diperlukan usaha keras dari semua lapisan masyarakat dan pemangku kebijakan. Secara normatif pemberantasan korupsi di Indonesia dilaksanakan dengan adanya Instruksi Presiden (Inpres) No. 5 Tahun 2004 tentang Percepatan Pemberantasan Korupsi. Intruksi khusus Presiden kesebelas memberikan instruksi kepada mendiknas (sekarang mendikbud) untuk menyelenggarakan pendidikan yang berisikan substansi penanaman semangat dan perilaku anti korupsi pada setiap jenjang pendidikan baik formal dan non-formal Hal ini merupakan suatu bentuk dari upaya pemerintahan dalam pemberantasan korupsi yang salah satunya melalui bidang pendidikan

Dalam dunia pendidikan diperlukan pengembangan pembelajaran nilai-nilai anti korupsi yang dimasukan pada seluruh jenjang pendidikan formal, informal maupun nonformal. Nilai-nilai anti korupsi sejatinya menjadi acuan dalam rangka mendidik agar memiliki karakter yang kuat 
dalam menghadapi kehidupannya di masa depan yang jauh dari korupsi. Komisi Pemberantasan Korupsi (2008: 2-42) merancang nilai-nilai anti korupsi yang ditanamkan pada siswa, yaitu: (1) tanggung jawab; (2) disiplin; (3) jujur; (4) sederhana; (5) kerja keras; (6) mandiri; (7) adil; (8) berani; (9) peduli.

Nilai-nilai antikorupsi tersebut perlu ditanamkan sejak dini dari mulai lingkungan keluarga. Selanjutnya sekolah juga seyogyanya menjadi tempat yang ideal dalam rangka menanamkan nilainilai anti korupsi. Fokus awal pananaman nilai-nilai antikorupsi adalah siswa menghayati, memahami nilai moral, membentuk prilaku sampai kemudian nilai tersebut terbentuk secara internal. Tujuan akhirnya adalah prilaku yang berdasarkan nilai-nilai positif tersebut diterapkan di lingkungan sosial masyarakat. Melihat pada nilai-nilai antikorupsi yang dikemukakan di atas, Pendidikan Kewarganegaraan seharusnya menjadi garda terdepan dalam pengembangan pembelajaran nilai-nilai anti korupsi. Good and smart citizen yang melekat pada Pendidikan Kewarganegaraan menjadi modal sekalligus tantangan untuk mewujudkan hal tersebut untuk menciptakan generasi baru yang terdidik dan anti korupsi di lingkungan sekolah.

Berdasarkan hasil observasi di Sekolah Menengah Pertama 02 Muhammadiyah Pontianak bahwa pelaksanaan Nilai-nilai sikap anti Korupsi pada diri siswa sudah dilaksanakan dalam proses pembelajaran pendidikan kewarganegaraan seperti kegiatan pembentuka karakter sikap anti korupsi, namun masih ada sebagian siswa yang kurang atau minimnya pemahaman maupun pengetahuan terhadap pentingnya sikap anti korupsi tersebut.Sehubungan dengan hal tersebut penulis merasa tertarik untuk mengadakan penelitian tentang "Analisis Pelaksanaan Nilai-nilai Sikap Anti Korupsi Dalam Pembelajaran Pendidikan Kewarganegaraan Pada Siswa Kelas VII SMP 02 Muhammadiyah Pontianak".

\section{METODE PENELITIAN}

Pelaksanaan penelitian ini menggunakan metode deskriptif kuantitatif, yang dimana dalam Metode penelitian kuantitatif Menurut Sugiyono (2015: 14), yaitu metode penelitian yang berlandaskan terhadap filsafat positivisme, digunakan dalam meneliti terhadap sample dan pupulasi penelitian, tehnik pengambilan sample umunya dilakukan dengan acak atau random sampling. Setelah dapat menentukan metode yang tepat, maka bentuk penelitian pun harus sesuai dengan metode yang dipergunakan. Sehubungan yang digunakan dalam penelitian ini adalah metode desktiptif maka bentuk penelitian yang digunakan adalah penelitian Studi survey (Survey studies). Hal ini sesuai dengan pendapat Nasution (2004: 84) yang mengatakan bahwa, "Suatu penelitian survey bertujuan untuk mengumpulkan informasi tentang orang yang berjumlah besar, dengan cara mewawancarai sejumlah kecil populasi itu. 
Teknik pengumpulan data yang digunakan dalam penelitian ini yaitu observasi langsung, komunikasi langsung dan komunikasi tidak langsung. Dimana observasi langsung bertujuan untuk mengamati dan mencatat gejala-gejala yang tampak pada objek penelitian, komunikasi langsung bertujuan mengumpulkan data yang mengharuskan seorang peneliti mengadakan kontak langsung secara lisan maupun tatap muka dengan responden yang ditujukan untuk guru Pendidikan Kewarganegaraan kelas VII dalam bentuk wawancara, dan komunikasi tidak langsung yang ditujukan kepada siswa siswi dalam bentuk angket pernyataan.

Subjek dalam penelitian ini adalah siswa kelas VII SMP 02 Muhammadiyah Pontianak. Dimana objek dalam penelitian ini berjumlah 31 orang yang terdiri dari 13 perempuan, 17 lakilaki dan 1 orang guru Pkn. Data yang dikumpulkan terdiri dari data primer dan data sekunder. Data primer diperoleh langsung melalui studi lapangan dengan menggunakan teknik observasi langsung dan wawancara yang dilakukan peneliti di lokasi penelitian, dan data sekunder diperoleh peneliti melalui komunikasi tidak langsung yang ditujukan kepada siswa dalam bentuk angket pernyataan.

Analisis data yang digunakan dalam penelitian ini adalah perhitungan statistik, dimana perhitungan ini sangat diperlukan dalam penelitian kuantitatif. Menurut Danang Sunyoto (2012: 1) mengatakan: "Statistik merupakan kumpulan cara atau metode dan aturan-aturan mengenai pengumpulan, pengolahan, penyajian, penganalisisan, serta menginterpretasikan data untuk mengabil keputusan". Perhitungan statistik yang dipergunakan dalam penelitian ini adalah menggunakan rumus persentase (\%) untuk menjawab sub masalah 1 (satu) sampai 3 (tiga). Menurut Mohamad Ali (1993: 148) rumus yang dimaksud adalah:

$$
\begin{array}{ll}
\mathrm{X} \% & =\frac{\mathrm{n}}{\mathrm{N}} \mathrm{X} 100 \% \\
\mathrm{X} \% & =\text { Persentase yang dicari } \\
\mathrm{n} & =\text { Jumlah Jawaban Responden } \\
\mathrm{N} & =\text { Jumlah Seluruh Jawaban }
\end{array}
$$

\section{HASIL DAN PEMBAHASAN}

Hasil penelitian yang telah dilakukan oleh peneliti bertempat di SMP 02 Muhammadiyah Pontianak dengan memperoleh informasi dan data yang diperlukan untuk memberikan jawaban terhadap rumusan masalah yang telah dirumuskan sebelumnya. Adapun hasil penelitian berdasarkan masalah penelitian berikut ini:

\section{Implementasi Nilai-Nilai Sikap Anti Korupsi Siswa Dalam Pembelajaraan Pendidikan Kewarganegaraan di kelas VII SMP 02 Muhammadiyah Pontianak.}

Analisis data tentang Implementasi nilai-nilai sikap anti korupsi siswa dalam Pembelajaraan Pendidikan Kewarganegaraan di kelas VII SMP 02 Muhammadiyah Pontianak, dapat dilihat pada table di bawah ini: 
Tabel 1

Hasil Jawaban Angket Implementasi Nilai-Nilai Sikap Anti Korupsi Siswa Dalam Pembelajaran Pendidikan Kewarganegaraan

\begin{tabular}{lcccc}
\hline \multicolumn{1}{c}{ Variabel /Aspek dan Indikator } & $\begin{array}{c}\text { S Skor } \\
\text { Aktual }\end{array}$ & $\begin{array}{c}\text { S Skor } \\
\text { Ideal }\end{array}$ & $\%$ & Kateogri \\
\hline $\begin{array}{l}\text { Implementasi nilai-nilai sikap anti korupsi } \\
\text { siswa dalam Pembelajaran Pendidikan }\end{array}$ & 1905 & 2160 & 88,19 & Sangat Baik \\
$\begin{array}{l}\text { Kewarganegaraan } \\
\text { 1. Kejujuran }\end{array}$ & 215 & 240 & 89,58 & Sangat Baik \\
2. Bertanggung Jawab & 220 & 240 & 91,67 & Sangat Baik \\
3. Keberanian & 209 & 240 & 87,08 & Sangat Baik \\
4. Kerja Keras & 182 & 240 & 75,83 & Sangat Baik \\
5. Keadilan & 221 & 240 & 92,08 & Sangat Baik \\
6. Kepedulian & 208 & 240 & 86,67 & Sangat Baik \\
7. Kedisiplinan & 225 & 240 & 93,75 & Sangat Baik \\
8. Kemandirian & 226 & 240 & 94,17 & Sangat Baik \\
9. Kesederhanaan & 199 & 240 & 82,92 & Sangat Baik \\
\hline
\end{tabular}

Berdasarkan tabel di atas dapat diinterprestasikan bahwa Implementasi nilai-nilai sikap anti korupsi siswa dalam Pembelajaran Pendidikan Kewarganegaraan pada siswa kelas VII SMP Muhammadiyah Pontianak mencapai skor aktual 1905 dan skor maksimal ideal 2160 dengan ratarata $88,19 \%$. Ini berarti Implementasi nilai-nilai sikap anti korupsi siswa dalam Pembelajaran Pendidikan Kewarganegaraan dalam kategori "Sangat Baik". Kategori sangat baik tersebut didukung oleh indikator pencapaian penelitian sebagai berikut: (1) Kejujuran sebesar 89,58\% dengan kategori Sangat Baik, (2) Bertanggung Jawab sebesar 91,67\% dengan kategori Sangat Baik, (3) Keberanian sebesar 87,08\% dengan kategori Sangat Baik, (4) Kerja Keras sebesar 75,83\% dengan kategori Sangat Baik, (5) Keadilan sebesar 92,08\% dengan kategori Sangat Baik, (6) Kepedulian sebesar 86,67\% dengan kategori Sangat Baik, (7) Kedisiplinan sebesar 93,75\% dengan kategori Sangat Baik, (8) Kemandirian sebesar 94,17\% dengan kategori Sangat Baik, (9) Kesederhanaan sebesar 82,92\% dengan kategori Sangat Baik. Jadi, hal inilah yang membuktikan bahwa Impelemntasi nilai-nilai sikap anti korupsi siswa dalam Pembelajaran Pendidikan Kewarganegaraan sudah dilaksanakan dengan sangat baik.

\section{Peran Guru Dalam Pelaksanaan Nilai-Nilai Pendidikan Anti Korupsi Pada Pembelajaran Pendidikan Kewarganegaraan Di kalas VIII SMP 02 Muhammadiyah Pontianak.}

Analisis data tentang Peran Guru Dalam Proses Pelaksanaan nilai-nilai pendidikan anti korupsi pada pembelajaran Pendidikan Kewarganegaraan Di kalas VIII SMP 02 Muhammadiyah Pontianak, dapat di lihat pada tabel di bawah ini:

\section{Tabel 2}

\section{Hasil Jawaban Angket Tentang Peran Guru Dalam Pelaksanaan Nilai-Nilai Pendidikan Anti Korupsi Pada Pembelajaran Pendidikan Kewarganegaraan}




\begin{tabular}{|c|c|c|c|c|}
\hline Variabel /Aspek dan Indikator & $\begin{array}{l}\sum \text { Skor } \\
\text { Aktual }\end{array}$ & $\begin{array}{l}\sum \text { Skor } \\
\text { Ideal }\end{array}$ & $\%$ & Kategori \\
\hline Variabel /Aspek dan Indikator & $\begin{array}{l}\sum \text { Skor } \\
\text { Aktual }\end{array}$ & $\begin{array}{c}\sum \text { Skor } \\
\text { Ideal }\end{array}$ & $\%$ & Kategori \\
\hline $\begin{array}{l}\text { Pelaksanaan nilai-nilai Pendidikan anti } \\
\text { korupsi dalam Pembelajaran } \\
\text { Pendidikan Kewaroaneogaran }\end{array}$ & 437 & 600 & 72,82 & Baik \\
\hline $\begin{array}{l}\text { a. Pengetahuan Tentang Korupsi } \\
\text { b. Pengembangan Sikap }\end{array}$ & $\begin{array}{c}60 \\
112\end{array}$ & $\begin{array}{l}120 \\
120\end{array}$ & $\begin{array}{l}50,00 \\
93,33\end{array}$ & $\begin{array}{l}\text { Cukup Baik } \\
\text { Sangat Baik }\end{array}$ \\
\hline c. Perubahan Sikap & 90 & 120 & 75,00 & Baik \\
\hline $\begin{array}{l}\text { d. Perspektif moral dan } \\
\text { konvensional }\end{array}$ & 60 & 120 & 50,00 & Cukup Baik \\
\hline $\begin{array}{l}\text { e. Pengembangan Karakter Anti } \\
\text { Korupsi }\end{array}$ & 115 & 120 & 95,83 & Sangat Baik \\
\hline
\end{tabular}

Berdasarkan tabel diatas dapat diinterprestaskan bahwa Pelaksanaan nilai-nilai Pendidikan anti korupsi dalam Pembelajaran Pendidikan Kewarganegaraan pada siswa kelas VII SMP Muhammadiyah Pontianak, mencapai skor aktual 437 dan skor maksimal ideal 600 dengan ratarata $72,82 \%$. Ini berarti Pelaksanaan nilai-nilai Pendidikan anti korupsi dalam Pembelajaran Pendidikan Kewarganegaraan dalam kategori "Baik" kategori baik tersebut didudung oleh indikator pencapaian penelitian sebagai berikut: (1) Pengetahuan tentang korupsi sebesar 50,00\% dengan kategori Cukup Baik, (2) Pengembangan Sikap sebesar 93,33\% dengan kategori Sangat Baik, (3) Perubahan Sikap sebesar 75,00\% dengan kategori Baik, (4) Perspektif moral dan konvensional sebesar 50,00\% dengan kategori Cukup Baik, (5) Pengembangan Karakter Anti Korupsi sebesar 95,83\% dengan kategori Sangat Baik.

\section{Faktor-Faktor Yang Mempengaruhi Pelaksanaan Nilai-Nilai Sikap Anti Korupsi Dalam Pembelajaran Pendidikan Kewarganegaraan pada siswa kelas VII SMP 02 Muhammadiyah Pontianak.}

Analisis data tentang Faktor-Faktor yang mempengaruhi pelaksanaan nilai-nilai sikap anti korupsi dalam pembelajaran Pendidikan Kewarganegaraan pada siswa kelas VII SMP 02 Muhammadiyah Pontianak, dapat di lihat pada tabel di bawah ini :

Tabel 3

Hasil Jawaban Angket Tentang Faktor-Faktor Yang Mempengaruhi Pelaksanaan Nilai-Nilai Sikap Anti Korupsi Dalam Pembelajaran Pendidikan Kewarganegaraan

\begin{tabular}{|c|c|c|c|c|}
\hline Variabel /Aspek dan Indikator & $\begin{array}{l}\text { Skor } \\
\text { Aktual }\end{array}$ & $\begin{array}{c}\sum \text { Skor } \\
\text { Ideal }\end{array}$ & $\%$ & Kategori \\
\hline $\begin{array}{l}\text { Faktor-Faktor yang mempengaruhi } \\
\text { Pelaksanaan nilai-nilai sikap anti Korupsi } \\
\text { dalam Pembelajaran } \\
\text { Kewarganegaraan } \\
\text { 1. Faktor Internal }\end{array}$ & 718 & 840 & 85,48 & Sangat Baik \\
\hline
\end{tabular}




$\begin{array}{lcccc}\text { a. Tidak memiliki sifat Tamak/rakus } & 108 & 120 & 90,00 & \text { Sangat Baik } \\ \quad \text { manusia } & 112 & 120 & 93,33 & \text { Sangat Baik } \\ \begin{array}{l}\text { b. Moral yang kuat } \\ \text { c. Gaya hidup yg tidak konsumtif }\end{array} & 74 & 120 & 61,67 & \text { Baik }\end{array}$

2. Faktor eksternal

a. Nilai - nilai di masyarakat sudah kondusif sehingga tidak mudah untuk terjadinya korupsi

$102 \quad 120 \quad 85,00 \quad$ Sangat Baik

b. Masyarakat menyadari bahwa korban utama korupsi adalah masyarakat sendiri.

c. Masyarakat menyadari bila dirinya terlibat korupsi.

$120 \quad 90,00 \quad$ Sangat Baik

$112 \quad 120 \quad 93,33 \quad$ Sangat Baik

d. Masyarakat menyadari bahwa korupsi akan bisa dicegah dan diberantas bila masyarakat ikut aktif dalam agenda pencegahan dan 102 120 85,00 Sangat Baik pmbrantasan.

Berdasarkan tabel diatas dapat disimpulkan bahwa faktor-faktor yang mempengaruhi Pelaksanaan nilai-nilai sikap anti Korupsi dalam Pembelajaran Pendidikan Kewarganegaraan pada siswa kelas VII SMP 02 Muhammadiyah Pontianak mencapai skor aktual 718 dan skor maksimal ideal 840 dengan rat-rata 85,48\%. Ini berarti Faktor-Faktor yang mempengaruhi Pelaksanaan nilainilai sikap anti Korupsi dalam Pembelajaran Pendidikan Kewarganegaraan dalam kategori "Sangat Baik". Kategori sangat baik tersebut didukung oleh indikator pencapaian penelitian sebagai berikut: (1) Faktor Internal, yang terdiri dari: (a) Tidak memiliki sifat tamak/rakus manusia sebesar 90,00\% dengan kategori Sangat Baik. (b) Moral yang kuat sebesar 93,33\% dengan kategori Sangat Baik. (c) Gaya hidup yang tidak konsumtif sebesar 61,67\% dengan kategori Baik. Sedangkan (2) Faktor Eksternal, yang terdiri dari: (a) Nilai - nilai di masyarakat sudah kondusif sehingga tidak mudah untuk terjadinya korupsi sebesar $85,00 \%$ dengan kategori Sangat Baik. (b) Masyarakat menyadari bahwa korban utama korupsi adalah masyarakat sendiri. Sebesar 90,00\% dengan kategori Sangat Baik (c) Masyarakat menyadari bila dirinya terlibat korupsi sebesar 93,33\% dengan kategori Sangat Baik (d) Masyarakat menyadari bahwa korupsi akan bisa dicegah dan diberantas bila masyarakat ikut aktif dalam agenda pencegahan dan pemberantasan sebesar 85,00 dengan kategori Sangat Baik.

\section{SIMPULAN}

Pelaksanaan nilai-nilai sikap anti korupsi dalam pembelajaran Pendidikan kewarganegaraan pada siswa kelas VII SMP Muhammadiyah Pontianak dapat dikategorikan sangat baik, hal tersebut dibuktikan dengan pencapaian pad aspek varibel yang mempeoleh skor aktual 3060 dan skor ideal 
3600 dengan angka persentase mencapai 85\% dengan kategori sangat baik. secara khusus penelitian ini dapat disimpulkan bahwa; (1) implementasi nilai-nilai sikap anti korupsi siswa dalam Pembelajaran Pendidikan Kewarganegaraan di kelas VII SMP 02 Muhammadiyah Pontianak memperoleh skor aktual 1905 dan skor ideal 2160 dengan angka persentase 88,19\% dengan kategori sangat baik; (2) proses pelaksanaan nilai-nilai Pendidikan anti korupsi dalam pembelajaran pendidikan kewarganegaraan di kelas VII SMP 02 Muhammadiyah Pontianak memperoleh skor aktual 437 dan skor ideal 600 dengan angka persentase 72,82\% dengan kategori Baik; (3) faktor-Faktor yang mempengaruhi pelaksanaan nilai-nilai sikap anti korupsi dalam pembelajaran pendidikan kewarganegaraan pada siswa kelas VII SMP 02 Muhammadiyah Pontianak memperoleh skor aktual 718 dan skor ideal 840 dengan angka persentase 85,48\% dengan kategori sangat baik.

\section{DAFTAR PUSTAKA}

Atmasasmita, R. (2004). Sekitar Masalah Korupsi. Aspek Nasional Dan Internasional. Bandung. Mandar Maju

Djaja, E. (2010). Memberantasa Korupsi Bersama KPK, Jakarta: Sinar Grafika

Harmanto. (2012). Pandangan Siswa Terhadap Korupsi dan Nilai-nilai Anti Korupsi.

Kesuma, D.,\& dkk. (2009). Korupsi Dan Pendidikan Anti Korupsi. Bandung: Pustaka Aulia Press. Instruksi Presiden No. 5 Tahun 2004 Tentang Percepatan Pemberantasan Korupsi

KPK. (2008). Buku Panduan Memberantas Korupsi. Jakarta: KPK

Mohamad Ali. (1993). Penelitian Kependidikan. Bandung: Angkas.

Novitasari. (2013). Implementasi Pembelajaran Pendidikan Kewarganegaraan Bermuaran Pendidikan Antikorupsi. Studi Deskriptif di SMA Negeri 8 Bandung. Bandung: Skripsi. Universitas Pendidikan Indonesia. Tidak Diterbitkan.

Supriatna. (2011). Internalisasi Nilai-nilai Anti Korupsi. Bandung: Alfabeta.

Sugiyono. (2008). Metode Penelitian Kuantitatif. Bandung: Alfabeta.

Sunyoto (2012). Dasar-Dasar Statistika Untuk Ekonomi. Yogyakarta: Caps Publishing

Nasution. (2004). Metode Research. Jakarta: Bumi Aksara.

Undang-Undang No. 20 (2003). Komisi Pemberantasan Korupsi.

Zuriah, N. (2007). Pendidikan Moral dan Budi Pekerti Dalam Perspektif Perbahan: Menggagas Platform Pendidikan Budi Pekerti Secara Kontektual dan Futuristik. Jakarta: Bumi Aksara 